\title{
Effect of Post-Weld Heat Treatment on the Corrosion Behavior of Resistance Spot Welded Super Duplex Stainless UNS S 32750
}

\author{
Byung-hyun Shin, Sanghyup Park, Junghyun Park, Dohyung Kim, \\ Myoungwon Hwang, and Wonsub Chung* \\ Pusan National University, Department of Materials Science and Engineering, Busan, Korea \\ *E-mail: wschung1@pusan.ac.kr
}

doi: $10.20964 / 2019.03 .14$

Received: 8 October 2018 / Accepted: 3 December 2018 / Published: 7 February 2019

\begin{abstract}
Super duplex stainless steel (SDSS) has high corrosion resistance. However, welding decreases its corrosion resistance due to the segregation of its major constituent elements by excessive ferritization in the weld zone (WZ) of SDSS. Increased welding current at resistance spot welding (RSW) increased the nugget size from $5.3 \mathrm{~mm}(6.0 \mathrm{kA})$ to $5.8 \mathrm{~mm}(8.0 \mathrm{kA})$, which in turn decreased the corrosion resistance. A larger WZ decreased the active potential $\left(\mathrm{E}_{\mathrm{corr}}\right)$ and increased the active current density ( $\mathrm{I}_{\text {corr }}$ ). Welded SDSS specimens exhibited heterogeneous pitting below the pitting potential. Heat treatment for a short time at a high temperature $\left(1200{ }^{\circ} \mathrm{C}\right)$ improved the corrosion resistance by modifying the volume fractions of austenite and ferrite. Heat treatment for 3 min resulted in the highest corrosion resistance, as an equal volume fraction of austenite and ferrite was achieved at this time.
\end{abstract}

Keywords: Super duplex stainless steel; Resistance spot welding; Welding current; Post-weld heat treatment; Corrosion behavior

\section{FULL TEXT}

(C) 2019 The Authors. Published by ESG (www.electrochemsci.org). This article is an open access article distributed under the terms and conditions of the Creative Commons Attribution license (http://creativecommons.org/licenses/by/4.0/). 